\title{
Compliance and leadership: the susceptibility of leaders to the risk of corruption in organizations
}

\author{
Compliance e liderança: a suscetibilidade dos líderes ao risco \\ de corrupção nas organizações
}

\author{
Renato Almeida dos Santos ${ }^{1}$, Arnoldo José de Hoyos Guevara ${ }^{1}$, Maria Cristina Sanches Amorim¹, \\ Ben-Hur Ferraz-Neto ${ }^{2}$
}

\begin{abstract}
In the field of organizational management, the term "compliance" designates the set of actions to mitigate risk and prevent corruption. Programs are composed by formal control systems, codes of ethics, educational actions, ombudsmen, and reporting channels - to mention the most recurrent, which vary according to the sector, the institutional culture, and the strategy. Leadership has a fundamental role in the process of compliance, not only due to its power to implement it, but precisely because it exercises this power, in itself, the object of reflections on ethics. The goal of this research was to evaluate the susceptibility of leaders to the risk of breaching organizational rules that involve ethical aspects. For quantitative investigation, we used social and descriptive statistical analysis of secondary data provided by ICTS Global, a company specialized in risk reduction. The study analyzed deals with non-probabilistic sampling by convenience, carried out between the years 2004 and 2008 with employees and candidates of 74 private companies located in Brazil. The final number of individuals studied is 7,267 . The indicators analyzed are contained in the index of moral perception of comprehension of individual vision of the concerning hypotheses of ethical conflicts. According to the information obtained in the investigation, leaders are more willing to fail to comply. Paradoxically, the data also show that leaders are more loyal to organizations, raising the hypothesis that the bent toward moral integrity and loyalty to the organization are not necessarily simultaneous behaviors (it is possible that, motivated by loyalty, a leader might break away from individual principles). Based on the data and on bibliographic references, our final considerations point to the importance of considering systems from which leadership is recruited, compensated, promoted, developed, etc., in the prevention of corruption. Our data do not show that leaders are more corrupt,
\end{abstract}

but that they have a greater disposition towards relaxing principles in professional circumstances.

Keywords: Guideline adherence; Leadership; Ethics, institutional

\section{RESUMO}

No campo da gestão organizacional, o termo "compliance" designa 0 conjunto de ações para mitigar o risco e prevenir corrupção. Os programas são compostos por sistemas de controles formais, códigos de ética, ações educativas, ouvidorias e canais de denúncia - para citar os mais recorrentes, que variam de acordo com o setor, a cultura institucional e a estratégia. A liderança tem papel fundamental no processo de compliance, não apenas pelo poder de implementá-lo, mas precisamente por exercer o poder, em si, objeto das reflexões sobre ética. 0 objetivo desta pesquisa foi avaliar a suscetibilidade dos líderes ao risco de descumprimento das regras organizacionais que envolvem aspectos éticos. Para a pesquisa quantitativa, utilizamos análise estatística social e descritiva de dados secundários cedidos pela ICTS Global, empresa especializada na redução de riscos. A pesquisa analisada trata de amostra não probabilística por conveniência, realizada entre os anos de 2004 e 2008, com funcionários e candidatos de 74 empresas privadas situadas no Brasil. 0 número final de indivíduos pesquisados totalizou 7.267. Os indicadores analisados estão contidos no índice de percepção moral de entendimento da visão do indivíduo frente a hipóteses de conflitos éticos. De acordo com as informações obtidas pela pesquisa, os líderes são mais dispostos à quebra do compliance. Paradoxalmente, os dados também mostram que líderes têm maior lealdade às organizações, levantando a hipótese de que disposição à integridade

\footnotetext{
Study carried out at: Pontifícia Universidade Católica de São Paulo - PUC-SP, São Paulo (SP), Brazil.

${ }_{1}$ Pontifícia Universidade Católica de São Paulo - PUC-SP, São Paulo (SP), Brazil.

${ }^{2}$ Hospital Israelita Albert Einstein - HIAE, São Paulo (SP), Brazil.

Corresponding author: Maria Cristina Sanches Amorim - Rua Ministro Godói, 969, $4^{0}$ andar, bloco A, sala 4E 04 - Perdizes - Zip code $05015-000$ - São Paulo - (SP), Brazil - Phone: (11) 3670 - 8513 E-mail: cris.amorim@pucsp.br

Received on: Jun 5, 2011 - Accepted on: Jan 12, 2012

Conflict of interest: None
} 
moral e lealdade à organização não são condutas simultâneas, necessariamente (é possível que, motivado pela lealdade, um líder rompa com princípios individuais). Apoiados nos dados e nas referências bibliográficas, nossas considerações finais apontam para a importância de serem considerados os sistemas a partir dos quais a liderança é recrutada, remunerada, promovida, desenvolvida etc., quando da prevenção da corrupção. Nossos dados não mostram que líderes sejam mais corruptos, mas que apresentam maior disposição à flexibilizar princípios nas circunstâncias profissionais.

Descritores: Fidelidade a diretrizes; Liderança; Ética institucional

\section{INTRODUCTION}

The term compliance is used to designate actions to mitigate risks and prevent corruption and fraud in organizations, regardless of the branch of activity ${ }^{(1)}$. Organizations may be regulated by public authority (such as in the case of sectors regulated by agencies) or simultaneously subordinated to laws both national and of other countries, such as the North-American law, Sarbanes-Oxley (SOX), from 2002, of which article 404 obligates public corporations to tailor the ethical behaviors of professionals and candidates, seek identification, mitigation, analysis of consequences, and prevention of inappropriate attitudes. The Law has the responsibility of punishing, when necessary; compliance actions have the responsibility of enclosing the problem of non-compliance with morally-based rules in the organization, even when they are not presented to Justice ${ }^{(1)}$.

The motivations for the adoption of compliance in organizations are varied. Corruption, in its various forms, leads to immediate financial loss, destroys the image and reputation of organizations, ruins the work environment, rends society, increases investment costs, and fuels practices that are harmful for economic and social development. Contrary to what economy analysts suggest, confidence among agents is at the base of business: most economic transactions are not supported by safety super systems, but by confidence ${ }^{(2-4)}$. An infallible control system, if it existed, would be more expensive than the potential benefit of vigilance.

A study by the Association of Certified Fraud Examiners $^{(5)}$ presents statistics from the Federal Board of Investigation of the United States indicating that a bank robber will take, in one action, approximately US\$ $12,000.00$, with one chance in nine of being arrested; a fraudster in a company will take an average of US $\$ 100,000.00$ with one chance in ten thousand of being arrested - and an even smaller chance that the victim will recover the resources withdrawn.

Behaviors with no ethical basis generate risks for the organization. Within the limits of our article, we consider only the operational risk, which implicates both internal risks - resulting from vulnerable processes and systems, besides inappropriate people - and external risks; and both require norms, procedures, and controls. In the field of compliance, operational risks can derive from internal and external risks; labor claims and deficient safety at the work place; inadequate practices relative to clients, products, and services; damage to one's own physical assets or those in use by the institution; interruption of activities of the institution; failures in information technology systems; failures in execution, in meeting deadlines, and in management of activities at the organziation ${ }^{(3)}$. The scope of our research covers only internal frauds - those committed within the organization.

Conduct between "according to the rule" (compliance) or corrupt, on the other hand, also has various causes, which, for the convenience of this exposition, we divided into those originated in individual decisions and in the context, or circumstances. In the first group are the values of people; in the second, the systems in which they work and the opportunity to do corrupt acts. Therefore, acts of compliance should seek to bring together both the quality of individuals relative to ethics and the formal instruments of control - one or the other isolated, as we shall see further on, is not effective. At the root of corrupt conduct is moral perception, the comprehension of the individual about the significance of his attitude as to morals and organizational rules ${ }^{(1)}$.

The statement is recurrent saying that the leader plays a fundamental role in organizations for any action: from innovation to strategy, from the adoption of the best management practices to the accreditation of the processes. What, then, is the peculiarity of the relation between compliance and leadership? The question is only answered if leadership is also understood as an exercise of power. In the case of innovation, strategy, or accreditation, for example, power is the necessary (albeit not sufficient) resource for implementation thus the importance of the leader, who holds a certain degree of power. In the case of compliance, the manner in which this power is exercised structures the potential for ethical correction or corruption of organizations: one employee may commit a fraud and cause losses, but the leader can institute a corrupt system that may become eternal. Authority exerted without ethical fetters and without rules can slide into tyranny, in the expression of Machiavelli( ${ }^{(6)}$, or, into the pursuit of personal interests in detriment of collective interests.

This article is organized into five sections. In the first, we present literature on compliance, highlighting the difficulties as to the definition of corruption, aligned 
with what we call three generations of approaches. The discussion about compliance expresses the effort of authors and managers in impeding corruption and promoting ethical attitudes in organizations. For this reason, despite the methodological limits, they seek to advance in the comprehension of the problem. We use the expressions "ethical" and "moral" as synonyms, despite the ample debate as to the differences between one and the other. In the second section, we offer a synthesis of the political theory that led us to treat leadership as an exercise of power, and its relations with compliance. In the third, the methodology of the investigation, which is quantitative-based, chosen in the attempt to better understand how leadership is exerted in relation to moral dilemmas. In the fourth section, we present the data obtained, and in the fifth, the conclusion.

\section{SECTION 1 - COMPLIANCE IN ORGANIZATIONS}

In organizations, compliance originated in financial institutions, with the creation of the Federal Reserve [American "Central Bank"] in 1913, with the objective, among other goals, of forming a more flexible, safe, and stable financial system. Soon after the crash of the New York Stock Exchange in 1929, the New Deal was created, that is, interventionist policy in the Economy to "correct the natural distortions of capitalism"(3). Despite its origin, compliance programs are not exclusive of banking institutions and basically encompass the search for agreement between individual and collective ethics - hence the expression, compliance, an Anglo-Saxon term originated from the verb "to comply," which means to act in accordance with a rule, a request, or a command. According to the Brazilian Federation of Banks (FEBRABAN), compliance is the obligation to fulfill, to be in conformity with, and to enforce internal and external regulations of a moral nature imposed on the activities of the institution ${ }^{(7)}$.

Operational risks may be mitigated with the use of information technology, implantation of standards of the best practices in services, constant monitoring of risks, and the prevention of events related to nonconformity $^{(3)}$. The objective aspects of reality most easily organized into quantitative indicators are highly privileged. The Basel Accord (international convention to regulate the world financial sector), known as Basel II, choses strict financial indicators as one of the main tools for determining the value of allocation of capital, which signifies that, by means of quantitative measurements, it is possible to define the degree of failures in internal controls relative to the confidence of the investors.
However, these instruments do not solve the problem; compliance programs should cover behavioral aspects which are, on the other hand, associated to values.

Studies on the cost-benefit ratio of implementing compliance programs in organizations show that every U\$ 1.00 spent means an economy of U\$ 5.00 with the mitigation of legal processes, damage to the reputation, and loss of productivity ${ }^{(8)}$. Data presented by Schilder explain that compliance is a distinguishing factor for competitiveness of organizations: besides reducing the potential cost, there are also benefits related to the share of the market that values transparency and ethics in economic and social interactions ${ }^{(8)}$.

The best practices can have a multiplying effect among organizations of the same sector. Let us analyze the causes. First, in order to minimize uncertainties, they may resort to benchmarking. Second, they are obligated to obey governmental regulating agencies. Third, the most efficient and high-quality standard can define the minimal limit of competition ${ }^{(9)}$. These three factors cause the "institutional isomorphisms" phenomenon ${ }^{(10)}$, a convergent movement among organizations of the same sector as to the model and practices of management. Isomorphism can create a virtuous dynamic of increased competitiveness and social gain. However, in addition to competitiveness gains and strengthening of market positions, organizations cannot escape practices related to compliance (reputation risks, for example, may be difficult to measure) cannot renounce principles based on ethics as legitimate values, regardless of financial gains $^{(8)}$.

\section{SECTION 2 - CORRUPTION: THEORY, INDICATORS AND RESEARCH}

According to the utilitarian-based economic theory, true economic players are governed by the pursuit of their own interests, by opportunism, and by the laborious search for advantages: agents agile in dissimulation obtain transactional advantages ${ }^{(11)}$. This behavior is called "rational egotism" - rationality is precisely the pursuit of private interest, at the lowest cost and greatest benefit. Therefore, part of economic analysis insists on the disqualification of ethics, in affirming that rational models are independent of considerations on ethical behavior, and are based exclusively on the attempt to maximize profit ${ }^{(12)}$.

Assuming the hypothesis of the rational egotist agent, the difficulties relative to ethics could be combated with the use of control instruments. This is the proposal of transaction costs economics, which admits the opportunistic potential of agents and 
adjusts the reality of organizations to this behavioral reference. It proposes a design of monitoring and control structures of the activities of those involved in organizational transactions according to their degree of sensitivity, since it is from this structure that operational costs are derived ${ }^{(13)}$. Hence, acquisition departments are considered more susceptible to corrupt practices and are therefore more closely watched.

The limits of transaction costs economics proposals in mitigating attacks on ethics in organizations are established by: (1) the controls that, albeit extremely sophisticated, do not foresee all the possibilities of fraud and are not infallible; (2) the weight of personal relations in the mitigation of or incentive for acts of bad faith; (3) costs of control may be significantly higher than the reduction of risks ${ }^{(14)}$.

At the origin of the proposals of transaction costs economics (a base rarely visible in the management tools of organizations) is the classic text by Adam Smith, The Theory of Moral Sentiments, written during the $17^{\text {th }}$ century ${ }^{(15)}$. Smith was a spectator of the industrial revolution, and understood the crucial importance of market expansion for the economic development of England. He sought to equate the tension between individual profit and collective well-being, since the pursuit of the first could occur at the expense of ethical conducts, which in turn were indispensable for survival of society. He came up with the maxim, repeated to exhaustion until the $21^{\text {st }}$ century, in which the various individual interests, when confronted on the market, would lead to the maximal collective well-being. To illustrate his opinions on the human behavior that should converge toward the general happiness, he used the metaphor of the "invisible hand"(15).

Despite popularity, the argument of the invisible hand should be compared with recent facts: bankruptcy of the North-American companies Enron and WorldCom, in 2001, of Lehman Brothers and Fannie Mae, in 2008, and even of the Brazilian Banco Panamericano, in 2011, for example, have, at their base, corruption of the primary officers ${ }^{(16)}$. Contrary to the theses based on transaction costs, there was no system capable of avoiding corruption, and, contradicting Smith ${ }^{(15)}$, the market did not guarantee the supremacy of collective interests: the invisible hand did not work.

Granovetter ${ }^{(14)}$ called analyses based on transition costs sub-socialized, since they do not allow the understanding that personal relations and their consequent obligations can intervene and mitigate the occurrence of acts of bad faith. At the other extreme, they identified super-socialization, the concept that confidence can substitute the control mechanism.
Super-control is unfeasible; there is no monitoring and control system that guarantees protection against bad faith acts or, at least, it would be impractical because of the cost of its execution (it could be more expensive than the object insured). To ignore formal controls betting on the absolute ethical correction of individuals or on the supremacy of feelings of understanding among them, as Smith ${ }^{(15)}$ suggests, also makes no sense. This led to more ample actions of compliance involving systems of control (that act upon the perception of opportunity for fraud) and behaviors.

The controversy on human nature, whether violent and aggressive or cordial, is ancient, and can be identified in Hobbes ${ }^{(17)}$ and Rousseau ${ }^{(18)}$, for example. In the $21^{\text {st }}$ century, we continue with no solution to the debate, but even so, we are pushed to create means of mitigating corruption. As shall be seen further along in the article, the combination of formal controls and the appreciation of ethical behaviors of leaders conform strategies for dealing with the problem within organizations.

The first generation of research investigates different views on corruption, without realizing the need to standardize the definition of corruption. The difficulty in attaining a consensus originates in the complex nature of the phenomenon, and for this very reason, it is studied by distinct disciplinary fields, such as philosophy, politics, behavioral sciences, economics, law, etc. ${ }^{(19,20)}$. Starting with the negative, corruption is not merely the use of public good for private purposes ${ }^{(21)}$; nor is it merely the result of human nature, but of social relations and circumstances. The research presented dealt only with information relative to conduct; therefore, we elected as definition of corruption:

"The social relation (of personal character, extramarket and illegal) that is established between two agents or two groups of agents (the corrupt and the corruptors), whose objective is the transferal of income from within society or the public fund for strictly private purposes. Such a relationship involves the exchange of favors among the groups of agents and generally the remuneration of the corrupt occurs with the use of kick-backs or any type of pay-off, premium, or recompense". ${ }^{(22)}$

The second generation of investigation of corruption generation is called investment risk identifiers. In the mid-1980s, companies sought signs of degrees of corruption as indications to aide decision-making tools for investments in a given country. This direct measurement is an insurmountable problem, since acts of corruption are secret, and the players identified as corrupt rarely confess the details of their illicit 
transactions, leaving only indirect indicators, which are severely criticized by the author ${ }^{(23)}$. For this reason, a ranking of the most corrupt countries, even those that are popular, has no solid conceptual and quantitative basis and, more importantly, does not help in understanding or in combating corruption.

The third generation of research appeared around the 1990's, with the purpose of improving the research results of corruption indicators considered innocuous; the determination that a given country was better or worse for investments added little value. The new proposal for research is based not only on identifying the problems that corruption can cause, but intends, first and foremost, to seek strategies to solve or mitigate corrupt acts and their consequences. Educational and punitive measures are valued, directing the focus towards positive and negative incentives that affect individuals. The objectives are reforms in the political and economic systems, attempting to identify structural or institutional causes of corruption. The investigation described in the present article is aligned with the group denominated "third generation research."

As presupposed, corruption in organizations is systemic. The subsystem of corruption is complex and difficult to disarticulate. In order to comprehend it, we list the following points, which are indicators of the amplitude of the causes of corruption ${ }^{(24)}$ :

I. there is a subsystem of reciprocity, which is destructive and parasitic, with mutual gains, in the exclusive networks of corruption;

II. extortion by public employees is a much greater problem than bribery, since it indicates a possible fragility in the state structure;

III. parasitic corruption behaviors may involve productive behaviors, which serve to support even more the subsystem of corruption;

IV. the small daily life traps and ethical violations may aggregate potential reformers, besides being used as weapons against them;

V. many of the agents of corruption, personally and individually, may be very pleasant, generous, interesting, intelligent, and even courageous persons, while at the same time they may also be parasitic and destructive;

VI. laws that are socially popular, but not realistic, are approved to generate political popularity and opportunities for extortion or bribery;

VII. there are corruption connections among political parties and the police and the branches of government responsible for prosecuting, judging, and legislating;

VIII. there are corruption connections among political parties and reports of potential "watch dogs" and research institutions, such as auditors, press, universities, and professional associations;

IX. the demands for generous funding of campaigns involve reform candidates and/or their family members and supporters in problematic financing relations;

$\mathrm{X}$. the participation in corruption of mutual gain is offered to potentially effective reformers, with attacks if the cooption is rejected, including gains on one side with losses on the other;

XI. conflicts with incentives of the primary agents of the public sector result in misunderstandings in regulations/rules and a relaxation in supervision, and this is not the same as deregulation or removal of governmental control;

XII. national and/or international rescue programs serve to maintain the corrupt system while at the same time forcing austerity measures for the middle and low classes.

As is presented, corruption in organizations opens a wide field for analysis, still marked by conceptual problems. Nevertheless, it is necessary to identify it, control it, and prevent it. From this comes the development of compliance, a theme that seeks to advance in the production of indicators and of actions to deal with corruption in organizations.

The discussion on compliance involves control systems (culture, values, processes, etc.). In the tradition of Foucault ${ }^{(25)}$, power is the relationship between people and is exerted by means of controls. To deal with control is to deal with one of the facets of power. If it is a relationship, it is possible to identify its subjects. The leaders, whether in an autocratic or democratic manner, subtle or explicit, exert the control, the power. Thus, leadership is understood as the exercise of power, and thus its specific role in compliance.

In the theory of organizations, leadership is a theory based on behavioral sciences, strongly divided between branches that give priority to personality traits, behaviors or situations, as to the definition of leader and his/her functions. For a general view of theories, Bergamini is recommended ${ }^{(26)}$. Our analysis of leadership is based on the contributions of politics ${ }^{(27)}$, from which we wove the interchange between leadership and compliance.

\section{Power, leadership and compliance in organizations}

The mitigation of internal corruption depends on the conformity among the rules of conduct of the organizations and of the individuals. The former needs to present the rules formally, even when the informal dimension of values does not cease to exist. The 
interests of the organizations and of the individuals are marked by conflicts and contradictions, relations of power that should submit to ethical rules. To disqualify the conflicts may be merely a naïve behavior ${ }^{(28)}$, such as, for example, the use of the expression "collaborators" to designate persons who work in the same organization under hierarchy and controls.

The definition of power is not unique. It varies among authors that confer to it positivity, such as Machiavelli( $^{(6)}$, Foucault ${ }^{(25)}$, and Gramsci( ${ }^{(29)}$, and the group that confers negativity, such as Hayek ${ }^{(30)}$. The negative association is that of common sense and of the majority of studies on organizations. In the first group, power is a resource, a discipline indispensable for the execution of collective projects, relations among people. In the second, it is submission and coercion, suppression of individual freedom. The discussion is naturally complex, although unnecessary for the objective of this article. It does interest us to highlight that the exercise of power is not bad in itself, as it may also be positivity. It is in this dimension of a necessary and inevitable resource that we use the term.

In managing systems of rewards, motivation, goals, evaluations, and all that conforms to its attributions, the leader exercises power, and the form of exercising it indicates his/her values and moral or ethical principles. In exercising power, the leader is faced immediately with the limits and possibilities of managing such a resource. Rules are necessary, and form a basis without which power would slide into tyranny, in the expression of Machiavelli( ${ }^{(6)}$, or, into the pursuit of private nonconfessable interests in detriment of collective interests. But rules are not enough; they do not form a super system of control, since ethical values also depend on the direction of the group.

Machiavelli's work is prescriptive (it intends to advise the prince), and interpretative (it presents and interprets phenomena of that time, without necessarily qualifying them as correct or wrong) $)^{(31)}$. In the interpretative field, it establishes differences between ethics of the follower and of the leader. To the former, correction is in fulfilling the role as citizen, with obedience to rules and discipline. The conduct of the leader, on the other hand, is marked even more intensely by circumstances or happenstance ("fortune"), and his/her attitudes have greater repercussion on the group than those of a common citizen, thus, the code for the leader cannot be the same. Along the same tradition, in the $20^{\text {th }}$ century, Gramsci ${ }^{(29)}$ pointed out the importance of discipline of the follower, understood not as subservience, but as overcoming the "animal individualism," as adherence to the rule exhaustively discussed and constructed on collective consensus.
Part of the literature on Machiavelli accuses him of dividing ethics into two parts, that of the government and that of the governed. However, it was also Machiavelli who highlighted the indissoluble relations between ethics and power, even if the exercise of power is strongly influenced by circumstances ${ }^{(31)}$.

In the tradition of Weber ${ }^{(32)}$, norms are instruments necessary to legitimate power. Programs of corporate compliance, such as a code of ethics, are presented as a manner of influencing the individual conduct expected by the leader from his/her follower. The approach with normative emphasis (compliance-based) is more common in traditional, hierarchical, and centralizing organizations. Organizations that have more participation, with a management that emphasizes culture as a source of attitudes (values-based) tend to favor actions of awareness and education to reinforce ethics and individual values ${ }^{(33)}$.

The leader needs to make good use of bureaucracy to balance the ethical conduct of the followers. Nevertheless, studies show that there is no direct relation between ethical conduct and codes of ethics ${ }^{(34)}$ when applied isolatedly ${ }^{(35)}$. We found no theoretical references to affirm that norms are sufficient for generating conformity of moral perception of the individual vis-à-vis the organizational ethical culture. When there is conformity between the individual ethical conduct and codes of ethics, when these reflect the organizational culture represented, the explicit rules gain importance ${ }^{(36)}$. Leadership, on the other hand, has importance in influencing the individual ethical conduct in organizations that endeavor to increase ethical consistency ${ }^{(37)}$, but also because the manner in which they exercise power establishes the type of alliance, whether centered around a publicly defensible project, or of the interests of an individual and of a group.

In the Florentine society described by Machiavelli( ${ }^{(6)}$, the leader did not need to have all the qualities, as long as he seemed to have them, that is, to adequately manage his image. In organizations of the $21^{\text {st }}$ century, the situation was radically modified: images separated from content do not resist the facility of communication of the most diverse media, which rarely lives to create or undo reputations. The knowledge accumulated around the best practices of leadership in organizations is unanimous as to the importance of consistency between discourses and actions of leadership, without which inadequate perceptions and values spread ${ }^{(38)}$ and power loses legitimacy. It is up to the leader to put forth the effort both in obedience to the rules (compliance-based), and in actions of awareness and adherence to ethics (values-based), or in how and why to exercise power. 
Pressured by the responsibility to attain goals, the leader may be particularly exposed to the risk of abandoning rules and ethics in making decisions ${ }^{(39)}$. Performance and ethics have no direct relation of causality: one individual may be competent technically and act in a completely anti-ethical manner, and viceversa $^{(40)}$, which dilates the possibility of the leader suffering and giving into pressure for results, even if for this he/she must relax his/her precepts.

\section{SECTION 3 - METHODS AND PRESENTATION OF THE INVESTIGATION}

This present project is exploratory ${ }^{(41)}$. It seeks to deepen knowledge of factors that influence organizational compliance. We used social and descriptive statistical analysis $^{(42)}$ of secondary data provided by ICTS Global $^{(43)}$, an international consulting company specialized in risk reduction to the estate, reputation, information, and life. The databank analyzed belongs to ICTS Global $^{(43)}$ that allowed its utilization; in the analysis, the confidentiality of subject identity and their respective organizations will be preserved.

The indicators analyzed are contained in the index of moral perception of comprehension of the vision of the individual as to hypotheses of ethical conflicts. These indicators are explained on table 1 and result from 140 questions asked by means of questionnaires and individual interviews in a business environment, following a scale from 1 (low), 2 (medium), and 3 (high) potential risk of non-adherence to company ethics, as was observed in the examples of questions on table 2 .

Table 1. Indicators studied and their significance from the AAEE database

\begin{tabular}{|c|c|}
\hline Indicator & Description \\
\hline Reporting & $\begin{array}{l}\text { Degree of probability of hesitating in denouncing an unethical deed that } \\
\text { occurred in the organization }\end{array}$ \\
\hline Errors & $\begin{array}{l}\text { Degree of probability of covering mistakes of work colleagues who } \\
\text { generated or could generate losses for the organization }\end{array}$ \\
\hline Camaraderie & $\begin{array}{l}\text { Degree of probability in living/working with unethical people in the work } \\
\text { place }\end{array}$ \\
\hline Guilt & $\begin{array}{l}\text { Degree of probability of blaming other colleagues from work for a } \\
\text { mistake they made }\end{array}$ \\
\hline Information & $\begin{array}{l}\text { Degree of probability of revealing confidential information to a person } \\
\text { not qualified to hear it }\end{array}$ \\
\hline Short-cuts & $\begin{array}{l}\text { Degree of probability of taking unethical short-cuts for personal benefit } \\
\text { (manipulation of results or payment of bribery) }\end{array}$ \\
\hline Theft & Degree of probability of theft of high value goods at the work place \\
\hline Bribery & Degree of probability of accepting bribery at the work place \\
\hline Presents & $\begin{array}{l}\text { Degree of probability of accepting presents of considerable value } \\
\text { coming from stakeholders }\end{array}$ \\
\hline
\end{tabular}

Source: AAEE Database. ICTS Global Ltda., 2009.
The study analyzed treats the non-probabilistic sample by convenience, performed between 2004 and 2008, with employees and candidates of 74 private companies located in Brazil. Using the AndersonDarling normality test, and considering a confidence levels of $95 \%$ and margin of error of $1.71 \%$ for more or for less, and working with a proportion of 0.005 , since the true proportion (p) is unknown, the final number of individuals researched totaled 7,574. Nonetheless, to analyze the variable "leadership," 307 investigations were discarded due to problems with filling out the papers, and only 7267 remained. The statistical software used to carry out such analyses was Minitab 2006. The demographic data of the individuals studied are detailed on table 3 .

As can be seen, the concentration of responders is in the field of wholesale and retail (47.2\%), followed by the area of services and financial holdings (23.3\%). This, however, does not suggest that the data are more akin to the analysis of these sectors. There is a concentration of responders with a level of tactical decision-making $(45 \%)$. The participants are concentrated in the salary level between $\mathrm{R} \$ 1,001$ and $\mathrm{R} \$ 7,000(66.3 \%)$. Most of the responders are employees $(62.9 \%)$ and more than half of them $(54.7 \%)$ have been in the organization for more than one year. Most $(69.2 \%)$ of the responders are male, all are older than 18 years of age, almost half $(48.3 \%)$ of them are aged between 25 and 34 years. For the purposes of analysis of this study, in the variable "age", we denominate as young adults those professionals aged 34 years and younger, and adults

Table 2. Examples of questions for the variables studied from the AAEE database

\begin{tabular}{ll}
\hline Indicator & \multicolumn{1}{c}{ Examples of questions } \\
\hline Reporting & $\begin{array}{l}\text { If you knew of something unethical that was happening in the company, } \\
\text { what would you do? }\end{array}$ \\
Errors & Would you cover up the mistakes of your work colleagues? \\
Camaraderie & Do you think it is advisable to hire a highly qualified professional if he/ \\
& she is not trustworthy? \\
Guilt & Would you blame another person for a mistake that you made, if you \\
& were running the risk of being fired? \\
Information & $\begin{array}{l}\text { What would you do if your new employer asked for confidential and } \\
\text { strategic information from your last company? }\end{array}$ \\
Short-cuts & $\begin{array}{l}\text { If you had the support of a superior, would you manipulate results to } \\
\text { improve the image of your area of work? }\end{array}$ \\
Theft & $\begin{array}{l}\text { Do you think that on certain occasions it is admissible for an employee } \\
\text { to steal from his employer? }\end{array}$ \\
Bribery & $\begin{array}{l}\text { What would you do if someone offered you a bribe? } \\
\text { What value would make you think of accepting a bribe? }\end{array}$ \\
Presents & $\begin{array}{l}\text { Do you think that an employee that accepted a present of merchandise } \\
\text { or equipment from a supplier should be punished? }\end{array}$ \\
\hline
\end{tabular}

Source: AAEE Database. ICTS Global Ltda., 2009. 
Table 3. Compilation of demographics of the AAEE database

\begin{tabular}{|c|c|c|}
\hline Variable & Description & Distribution (\%) \\
\hline \multirow[t]{5}{*}{ Segment } & Retail & 47.2 \\
\hline & Construction and industry & 8.5 \\
\hline & Services and financial holdings & 23.3 \\
\hline & Logistics and transportation & 14.1 \\
\hline & Telecommunications and information & 6.9 \\
\hline \multirow[t]{2}{*}{ Public } & Candidate & 37.1 \\
\hline & Employee & 62.9 \\
\hline \multirow[t]{4}{*}{ Time in company } & Candidate & 37.1 \\
\hline & Less than 1 year & 8.2 \\
\hline & 1 to 5 years & 19.9 \\
\hline & More than 5 years & 34.8 \\
\hline \multirow[t]{2}{*}{ Gender } & Male & 69.2 \\
\hline & Female & 30.8 \\
\hline \multirow[t]{5}{*}{ Age group } & $18-24$ & 9.2 \\
\hline & $25-34$ & 48.3 \\
\hline & $35-44$ & 29.5 \\
\hline & $45-54$ & 10.6 \\
\hline & $>55$ & 2.3 \\
\hline \multirow[t]{2}{*}{ Age } & Young adult ( $<34$ years) & 55.5 \\
\hline & Adult (> 34 years) & 44.5 \\
\hline \multirow[t]{9}{*}{ Basic schooling } & Incomplete elementary school & 2.6 \\
\hline & Complete elementary school & 0.4 \\
\hline & Incomplete high school & 18.8 \\
\hline & Complete high school & 1.7 \\
\hline & Incomplete college & 32.9 \\
\hline & Complete college & 18.2 \\
\hline & Graduate studies & 22.5 \\
\hline & Masters & 2.7 \\
\hline & Doctorate (PhD) & 0.2 \\
\hline \multirow[t]{2}{*}{ Formal education } & Undergraduate* & 56.5 \\
\hline & Graduate** & 43.5 \\
\hline \multirow[t]{5}{*}{ Salary range } & Up to $R \$ 1,000.00$ & 9.4 \\
\hline & $R \$ 1,001.00$ to $R \$ 3,000.00$ & 35.2 \\
\hline & $R \$ 3,001.00$ to $R \$ 7,000.00$ & 31.1 \\
\hline & $R \$ 7,001.00$ to $R \$ 15,000.00$ & 18.3 \\
\hline & More than $\mathrm{R} \$ 15,001.00$ & 6.0 \\
\hline \multirow{4}{*}{$\begin{array}{l}\text { Place of } \\
\text { residence }\end{array}$} & Sao Paulo & 57.8 \\
\hline & Rio de Janeiro & 19.6 \\
\hline & Center-West/Southwest & 9.2 \\
\hline & North/Northeast & 7.1 \\
\hline \multirow[t]{3}{*}{ Hierarchy } & Operational & 32.0 \\
\hline & Tactical & 45.0 \\
\hline & Strategic & 23.0 \\
\hline
\end{tabular}

Source: AAEE Database. ICTS Global Ltda., 2009.

*Undergraduate: Incomplete Elementary, High School and College degree; ${ }^{* *}$ graduate: complete college courses and graduate studies. as those above this age. They $(43.5 \%)$ are graduates (complete college and/or graduate work). Due to the high concentration of participants in the Southeast region of the country (77.4\%), we separated the States of São Paulo and Rio de Janeiro from this region. We did not consider the States in which fewer than five research processes were applied.

We denominated as leader only those professionals with levels of strategic decision-making (presidents, executive directors, and managers of the first hierarchical level), amassing with this a sample of $23 \%$ of the database.

\section{SECTION 4 - ANALYSIS AND INTERPRETATION OF RESULTS}

In table 4, a comparative analysis is presented for the variable "leadership" with regards to indicators of moral perception, with the differences among responders who were leaders and followers, and in figure 1, these differences are exposed in a graphic manner, in which one can note very significant differences in 9 of the 11 indicators of moral perception of the AAEE database from ICTS Global.

According to the information obtained by the study, as to leaders it is correct to say that:

1. they tend to hesitate more in reporting unethical acts committed by work colleagues, as well as in covering up mistakes made by these same colleagues;

2. they have greater tolerance towards working side by side with dishonest persons in the professional environment;

3. they are more likely to blame other work colleagues for mistakes in which they contributed;

4. they tend to have greater potential for adopting unethical short-cuts to attain goals, just as they have done in the past (more than the followers);

5. they have greater potential for accepting presents coming from stakeholders than the followers do, and with this, greater probability of having conflicts of interest among them in commercial negotiations or in decisions between products or services;

6. they presented a greater incidence of firing due to problems related to ethics (pointing out that, possibly, the higher the hierarchical level, the greater professional experience, enabling a higher incidence).

Table 5 presents the results on the degree of loyalty of employees towards the organizations in which they work, whereas the leaders tend to be more loyal to the organization than the followers, and yet, the $p$ value indicates that this difference is significant $(10 \%$ 
Table 4. Comparative analysis in the leadership variable relative to indicators of moral perception

\begin{tabular}{lccccc}
\hline Indicator & Follower & Leader & t value & p value* & \\
\hline Reporting & 1.687 & 1.836 & 6.76 & 0.000 & $* * *$ \\
Errors & 1.703 & 1.822 & 5.55 & 0.000 & $* * *$ \\
Camaraderie & 1.557 & 1.730 & 7.86 & 0.000 & $* * *$ \\
Guilt & 1.087 & 1.111 & 2.51 & 0.012 & $* *$ \\
Information & 1.242 & 1.227 & -1.17 & 0.242 & \\
Short-cuts & 1.378 & 1.507 & 6.90 & 0.000 & $* * *$ \\
Theft & 1.123 & 1.100 & -2.43 & 0.015 & $* *$ \\
Bribery & 1.387 & 1.377 & -0.59 & 0.557 & \\
Presents & 1.334 & 1.412 & 4.49 & 0.000 & $* * *$ \\
\hline
\end{tabular}

Source: AAEE Database. ICTS Global Ltda., 2009.

${ }^{* *} p<0.05 ;{ }^{* * *} p<0.01$.

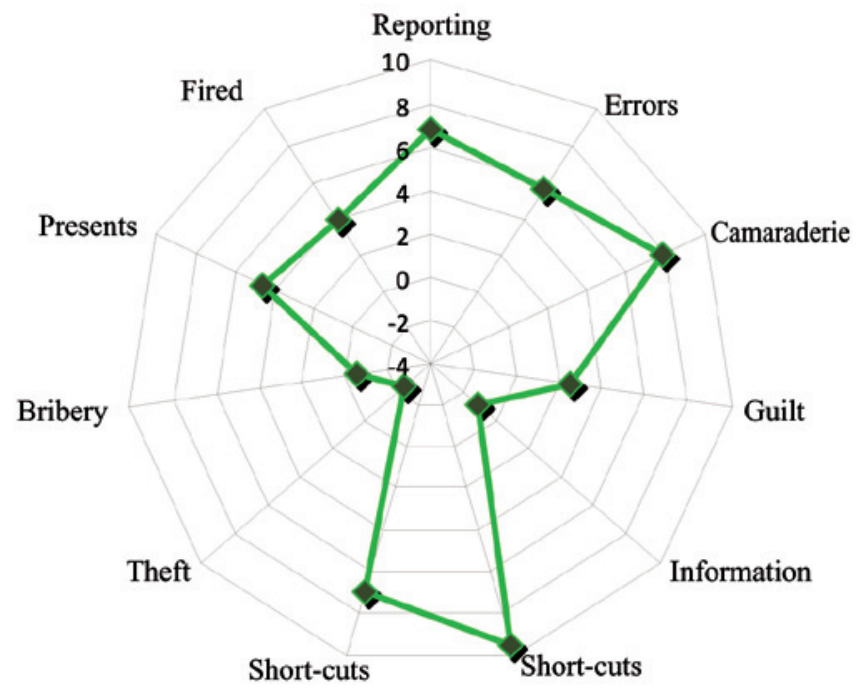

Source: AAEE database. ICTS Global Ltda., 2009.

Figure 1. Comparative graph of the leadership variable relative to indicators of moral perception using the significant values of " $\mathrm{t}$ " (among the highest plus the difference between leader and follower).

level) even in comparison with the other indicators presented in this study. We highlight that the leader may be more loyal to the interests of the organization, even in detriment to his/her own ethical perceptions or that he/she can be disloyal and have rigid and consistent moral values. Still, he/she may be loyal to the point of submitting his/her own ethical principles to the values of the organization, in case they have flexibility that allows this - and thus the relevance of raising the analysis of this indicator.

The unconditional loyalty of the leader towards the organization may be damaging to integrity, leading to an ethical dilemma and the "fragmentation of the self"(44).
Table 5. Comparative analysis between the variable leadership and the indicator of disloyalty towards the organization

\begin{tabular}{lcccc}
\hline Indicator & Follower & Leader & t value & p value \\
\hline Disloyalty & 1.405 & 1.376 & 3.73 & 0.054 \\
\hline $\begin{array}{l}\text { Source: AAEE database. ICTS Global Ltda., 2009. } \\
{ }^{*}{ }_{p}<0.10\end{array}$ & & &
\end{tabular}

\section{SECTION 5 - CONCLUSION}

The study of the contributions of political theory allowed us to locate in history the discussion with respect to ethics, power, and leadership. The expression "compliance" may be considered recent, but the debate about ethics and corruption has been present since antiquity. And since that time, there have been recommendations to understand the exercise of power and of the function of leadership when the objective is to avoid corruption and promote ethical behavior. Instead of the eternal controversy between collective and individual needs, Adam Smith, a follower of other philosophers, decided in favor of the invisible hand that assuages the consciousness: let each one attend to his/her own life according to his/her own interests and sleep in peace, since the collective well-being would result naturally from the individual. When the topic is the source and coherence between values and the conduct of the leader, Machiavelli justified his Prince as being regulated by ethics different from that of the followers. In democratic and constitutional societies, Machiavelli's argument lost its legitimacy: on the contrary - it is expected of the leader precisely that he give the example of ethical correctness as a form of exerting power, from true behavior to the rules.

This study was inspired by the discussion on power, ethics, and context to research and analyze the sensitivity of leaders to the decisions that involve ethics. We hope to contribute to a more attentive look at the importance of leadership (and all that this involves) in the implementation of compliance programs. This means special care in the selection, hiring, and evaluation of leaders: it is not uncommon for systems of remuneration by performance to not collaborate towards the observance of ethics. There is a dose of schizophrenia in marking severe goals and inexorable punishments, besides intending that conducts will not react outside the limits of compliance.

Since he/she exercises the power, the leader is exposed more intensely to the choices that involve ethical dilemmas, his/her actions have greater consequences on the group, and his/her responsibilities are greater. If the behavior of the leader is strongly influenced by the context, or fortune, the pressures for the results and the culture or fortune, the pressures for results 
and the permissive organizational culture do not help ethical behaviors. Individual behaviors based on ethical principles are fundamental, but they cannot resist general systems that promote corruption, such as, for example, lack of transparency, excessively hierarchy, with controls that are intense and useless to the results, etc.

This study did not raise the causes of greater sensitivity of leaders to the risk of non-compliance only literature points to some clues - of rules relative to ethics; even so, we suggest that future surveys investigate the distortions brought by the programs of explicit recompenses turned towards themselves at the time of implementation of compliance programs.

The data presented here point to a greater sensitivity of the leader to transgression of norms for compliance and, simultaneously, to greater loyalty towards the organization. If a nonchalant organizational culture as to ethics and a high level of loyalty are combined, the results in individual behavior may be disastrous for the organization over the medium- and long-term. Printed rules and control systems are not sufficient for impeding the generalization of inadequate or even corrupt behaviors.

\section{REFERENCES}

1. Santos RA. Compliance como ferramenta de mitigação e prevenção da fraude organizacional [dissertação]. São Paulo (SP): PUC-SP; 2011.

2. Arruda MC, Whitaker MC, Ramos JM. Fundamentos de ética empresarial e econômica. 2a ed. São Paulo: Atlas; 2001.

3. Manzi VA. Compliance no Brasil: consolidação e perspectivas. São Paulo: Saint Paul; 2008.

4. Morgado F. Confiança na comunicação das informações econômico-financeiras: 0 caso das empresas de autogestão [tese]. São Paulo (SP): PUC-SP; 2008.

5. Association of Certified Fraud Examiners. Fraud examiners manual. 3rd ed. Austin: ACFE; 1993.

6. Machiavelli N. 0 príncipe escritos políticos. São Paulo: Abril Cultural; 1973.

7. Morais EJ. Controles internos e estrutura de decisão organizacional: o caso da contadoria do Banco do Brasil [dissertação]. Curitiba (PR): UFPR; 2005

8. Schilder A. Banks and the compliance challenge. The Asian Banker Summit; 2006 Mar 15 - Mar 17; Bangkok: Bank for International Settlelments; 2006.

9. Daft RL. Organizações: teoria e projetos. São Paulo: Pioneira Thomson Learning Daft RL; 2002.

10. DiMaggio PJ, Powell WW. The iron cage revisited: institutional isomorphism and collective rationality in organizational fields. Am Sociol Rev.1983; 48(2):147-60

11. Williamson OE. The mechanisms of governance. New York: Oxford University Press; 1996

12. Demsetz H. The economics of the business firm: seven critical commentaries. Cambridge: Cambridge University Press; 1996.

13. Zylbersztajn D. Organização ética: um ensaio sobre comportamento e estrutura das organizações. Rev Adm Contemp. 2002;6(2):123-43.

14. Granovetter M. Economic action and social structure: the problem of embeddedness. AJS. 1985;91(3):481-510.
15. Smith A. Teoria dos sentimentos morais. São Paulo: Martins Fontes; 2002

16. Perillo EB, Amorim MC. Reflexões sobre análise de desempenho. Para entender a saúde no Brasil 4. São Paulo: LCTE; 2011.

17. Hobbes T. Do cidadão. São Paulo: Martins Fontes; 1992.

18. Rousseau JJ. Os pensadores. Editado por Victor Civita. São Paulo: Abril Cultural; 1978.

19. Speck BW. Mensurando a corrupção: uma revisão de dados provenientes de pesquisas empíricas. Cadernos Adenauer 10: os custos da corrupção. Fortaleza (CE): Fundação Konrad Adenauer; 2000.

20. Brei ZE. Corrupção: dificuldades para definição e para um consenso. Rev Adm Pública. 1996;30(1):64-77.

21. Nye JS. Corruption and political development: a cost-benefit analysis. Am Polit Sci Rev. 1967;61(2):417-27.

22. Controladoria-geral da União (CGU), Instituto Ethos de Empresas e Responsabilidade Social e Grupo de Trabalho do Pacto Empresarial pela Integridade Contra a Corrupção. A Responsabilidade Social das empresas no combate à corrupção [Internet]. 2009. [citado 2011 Dez 14). Disponível em: www.empresalimpa.org.br

23. Abramo CW. Percepções pantanosas. A dificuldade de medir a corrupção. Novos estudos. CEBRAP; 2005.

24. Nielsen RP. Corruption networks and implications for ethical corruption reform. J Bus Ethics. 2003;42(2):125-49.

25. Foucault M. Microfísica do poder. 11a ed. Rio de Janeiro: Graal; 1995.

26. Bergamini CW. Liderança - administração do sentido. 3a ed. Atlas; 1994.

27. Amorim MC, Peres RH. Poder e liderança. As contribuições de Maquiavel, Gramsci, Hayek e Foucault. [publicado pela XXXI EnANPAD; 2007; Rio de Janeiro,RJ].

28. Giddens A. Política, sociologia e teoria social. São Paulo: Fundação Editoria UNESP; 1998.

29. Gramsci A. Obras escolhidas. 2a ed. São Paulo: Brasiliense; 1992.

30. Hayek F. 0 caminho da servidão. 4a ed. Rio de Janeiro: Instituto Liberal; 1987.

31. Bignoto N. As fronteiras da ética: Maquiavel. In: Novaes A, organizador. Ética. São Paulo: Cia. das Letras; 1992.

32. Weber M. Economia e sociedade: fundamentos da sociologia compreensiva. 4a ed. Brasília, DF: UnB, 2004.

33. Hoivik HW. Professional ethics: a managerial opportunity in emerging organizations. J Business Ethics. 2002;39(1):3-11.

34. Cherman A, Tomei PA. Códigos de ética corporativa e a tomada de decisão ética: instrumentos de gestão e orientação de valores organizacionais? Rev Adm Contemp. 2005;9(3):99-120.

35. Mathews MC. Codes of ethics: organizational behavior and misbehavior. In: Frederick WC, editor. Connecticut: research in corporate social performance and policy. Greenwich, CN: JAI Press;1987. v. 9. p. 107-30.

36. McCabe DL, Treviño LK, Butterfield KD. The influence of collegiate and corporate codes of conduct on ethics-related behavior in the workplace. Bus Ethics 0. 1996;6:461-76.

37. Arruda MC, Navran F. Indicadores de clima ético nas empresas. Rev Adm Empres. 2000;40(3):26-35.

38. Paine LS. Managing for organizational integrity. Harv Bus Rev. 1994;72(2):106-17.

39. Badaracco JLJr, Webb AP. Business ethics: a view from the trenches. Calif Manage Rev. 1995;37(2):8-28.

40. Borini FM, Grisi FC. A corrupção no ambiente de negócios: survey com as micro e pequenas empresas da cidade de São Paulo. R Adm. 2009;44(2):102-17.

41. Collins J, Huassey R. Pesquisa em administração. 2a ed. Porto Alegre: Bookman; 2005.

42. Babbie E. Métodos de pesquisa de survey. Belo Horizonte: UFMG; 2003.

43. ICTS Global. Análise de Aderência à Ética [Internet]. 2010. [citado 2011 Dez 14]. Disponível em: www.ictsglobal.com

44. Nash LL. Ética nas empresas: boas intenções à parte. São Paulo: Makron Books; 1993. 